\title{
Analisis Potensi Materi Ajar Biologi SMP Berbasis pada Potensi Lokal dari Area Sungai Gajah Wong Kabupaten Bantul
}

\author{
Muhammad Joko Susilo \\ Progam Studi Pendidikan Biologi, Universitas Ahmad Dahlan \\ Kampus III, J1. Prof. Dr. Soepomo, SH, Yogyakarta, 55164 Indonesia \\ surat elektronik: jokoms_uad@yahoo.com
}

\begin{abstract}
ABSTRAK
Kebutuhan akan materi pembelajaran yang berbasis pada potensi lokal belum banyak ditemukan dalam referensi/buku pegangan guru. Materi ajar yang kontekstual sangat diharapkan dalam pengembangan standar isi pada Kurikulum 2013. Penelitian ini bertujuan untuk: (I) mengetahui potensimateri ajar biologi yang ditemukan di wilayah Kabupaten Bantul, (2) mengetahui kesesuaian temuan-temuan materi berbasis potensi lokal dengan kebutuhan materi ajar biologi SMP yang memenuhi prinsip-prinsip relevansi, adequacy, dan konsistensi, dan (3) mengetahui kualitas prototipe/desain suplemen materi ajar yang dikembangkan dengan isi/bahan materi ajar berbasis potensi lokal untuk 3 Kompetensi Dasar versi Kurikulum 2013 di jenjang SMP.

Penelitian ini didesain denganfragmen/penggalan dari penelitian pengembangan dengan langkah analisis kebutuhan dilakukan melalui penelitian eksplorasi di sungai gajah wong Kabupaten Bantul, selanjutnya dilakukan penelaahan mendalam tentang materi ajar yang ditemukan dari penelitian eksplorasi, dan dilanjutnya dengan mengembangkan prototipe suplemen materi ajar biologi SMP. Pengumpulan data dilakukan dengan observasi dan dokumentasi. Teknik analisis data dilakukan secara diskriptif kualitatif.

Hasil penelitian menunjukkan potensi materi ajar yang ditemukan Sungai Gajah Wong cocok untuk materi klasifikasi hewan invertebrata. Selanjutnya, hasil analisis mendalam ditemukan materi ajar yang ditemukan sudah memenuhi kriteria materi ajar yang mencakup pengetahuan, sikap, dan ketrampilan juga memenuhi prinsip pengembangan materi yaitu relevansi, adequacy, dan konsistensi. Hasil pengujian kualitas suplemen materi ajar menunjukkan bahwa suplemen materi ajar klasifikasi hewan invertebrate dinyatakan layak dengan kategori baik.
\end{abstract}

Kata kunci: pengembangan, suplemen materi ajar IPA (Biologi), potensi lokal

\section{Pendahuluan}

Adanya kebijakan penggantiankurikulum secara tidak langsung mengajak para gurukhususnya yang mengampu mata pelajaran IPA (biologi) untuk mempersiapkan materi yang akan diajarkan dengan baik. Materi pembelajaran yang dipersiapkan harus sesuai dengan arah kebijakan yang tertuang dalam kurikulum dan sesuai dengan tuntutan serta kebutuhan masyarakat. Oleh karena itu, untuk mengembangkan kurikulum yang akan diterapkan seorang guru harus mengacu pada Undang-Undang No. 20 Tahun2003 yang menyebutkan bahwa pengembangan kurikulum dilakukan dengan mengacu pada Standar Nasional Pendidikan dan kurikulum pada semua jenjang dan jenis pendidikan dikembangkan dengan prinsip diverifikasi sesuai dengan satuan pendidikan, potensi daerah, dan peserta didik.
Peraturan Pemerintah No. I9 Tahun 2005 menyebutkan bahwa standar yang terkait langsung dengan kurikulum adalah Standar Isi dan Standar Kompetensi Lulusan, dan telah diatur dalam Peraturan Menteri Pendidikan Nasional No. 22 Tahun 2006 tentangStandar Isi (SI) dan Peraturan Menteri Pendidikan Nasional No. 23 Tahun 2006 tentang Standar Kompetensi Lulusan (SKL) serta Peraturan Menteri Pendidikan Nasional No. 24 Tahun 2006 tentang Pelaksanaan SI dan SKL. Berdasarkan SI dan SKL, serta panduan yang disusun oleh BSNP, maka Satuan Pendidikan diharapkan dapat mengembangkan kurikulum sesuai dengan satuan pendidikan, potensidaerah/karakteristik daerah, social budaya masyarakat setempat, dan peserta didik.

Mengacu pada hasil penelitian Suratsih (2010) tentang pelaksanaan pembelajaran IPA KTSP SMP di Kabupaten Sleman Yogyakarta, menunjukan bahwa, 
potensi local yang dimiliki sekolah belum dimanfaatkan secara optimal dalam kegiatan pembelajaran biologi, sedang pemanfaatan potensi sekolah merupakan salah satu karakteristik dalam pengembangan kurikulum, dan guru-guru biologi belum banyak berkarya untuk mengembangkan materi biologi yang berbasis potensi lokal/karakteristik yang ada di daerah setempat. Guru masih banyak menggunakan sumber belajar yang sudah tersedia di pasaran yang tidak cocok dengan kondisi sekolah maupun karakteristik siswa, sehingga masih harus dilakukan penyesuaian-penyesuaian. Berdasarkan argument tersebut, maka guru untuk berinovasi dan berkarya dengan mengkaji dan menyiapkan subject matter seoptimal mungkin yang berbasis pada potensi lokal/kedaerahan. Untuk itulah, usulan penelitian diajukan dalam satu paket penelitian pengembangan yang dipetakan dalam beberapa tahap pengembangan. Namun, karena ada keterbatasan maka dalam penelitian hanya diambilkan fragmen/penggalan alur riset pengembangan yaitu: ekplorasi dan analisis potensimateri IPA (biologi) berbasispotensialam di Kabupaten Bantul sampai pada desain buku suplemen materi ajar yang berisi materi biologi SMP dengan mengangkay persoalan apa saja temuan-temuan materi berbasis potensi lokal tersebut sesuai dengan kebutuhan materi ajar biologi SMP dan memenuhi prinsip-prinsip relevansi, adequacy, dan konsistensi untuk membelajarkan biologi di jenjang SMP?; Bagaimanakah kualitas buku suplemen materi ajar yang dikembangkan berbasis potensi lokal di jenjang SMP?

\section{Metode Penelitian}

Penelitian ini didesain dengan fragmen/penggalan dari penelitian pengembangan dengan langkah analisis kebutuhan dilakukan melalui penelitian eksplorasi di sungai gajah wong Kabupaten Bantul. Subjek penelitian ini adalah guru biologi SMP. Pengambilan subjek guru dilakukan dengan teknik purposive random sampling. Langkah-langkah untuk mendapatkan data dalam rangka penyusunan buku suplemen materi ajar sebagai berikut: Melakukan penelitian eksplorasi potensi alam yang ada diwilayah Kabupaten Bantul, DIY sebagai sumber belajar IPA (biologi) untuk bahan penyusunan materi ajar biologi berbasis potensi local; Melakukan penelahaan hasil kajian penelitian eksplorasi untuk diidentifikasi potensi sebagai materi ajar biologi di jenjang SMP yang sesuai dengan Kurikulum 2013; Mendesain prototipe suplemen materi ajar sebagai wadah dari materi yang ditemukan dari hasil penelitian eksplorasi; Mengujikan desain buku suplemen materi ajar untuk mendapatkan kualitas dari isi materi ajar yang ditemukan; dan Menganalisis hasil pengujian desain buku suplemen materi ajar melalui uji terbatas oleh guru IPA (Biologi SMP). Pengumpulan data dilakukan dengan observasi dan dokumentasi. Teknik analisis data dilakukan secara diskriptif kualitatif.

\section{Hasil dan Pembahasan}

\section{Hasil Temuan Materi Ajar Biologi}

Tabel I. Kesesuaian temuan materi ajar klasifikasi invertebrata berdasarkan hasil penelitian di area Sungai Gajah Wong

\begin{tabular}{ccccc}
\hline K / & Materi Ajar Tuntutan & K / & Materi Ajar Hasil Penelitian di & Sungai Gajah Wong \\
SK & Kurikulum 2013 & SK & Keterangan \\
\hline K & Klasifikasi & K & Klasifikasi & \\
\hline
\end{tabular}

SK-I $\begin{aligned} & \text { Tujuan dan manfaat } \quad \text { SK-I Tujuan dan manfaat klasifikasi } \\ & \text { klasifikasi }\end{aligned}$

Terpenuhi. Dari mengenal berbagai spesies makhluk hidup, hubungan kekerabatan, dan interaksi antarmakhluk hidup.

\begin{tabular}{llll}
\hline SK-2 $\begin{array}{l}\text { Prosedur pengklasifikasian } \\
\text { makhluk hidup }\end{array}$ & SK-2 $\begin{array}{l}\text { Prosedur pengklasifikasian hewan } \\
\text { invertebrata }\end{array}$ & $\begin{array}{l}\text { Terpenuhi. Didasarkan pada persamaan } \\
\text { dan perbedaan ciri-ciri morfologi yang } \\
\text { dimiliki. }\end{array}$ \\
\hline SK-3 Tata nama makhluk hidup & SK-3 Tata nama makhluk hidup & $\begin{array}{l}\text { Terpenuhi. Menggunakan sistem tata nama } \\
\text { binomial nomenclature, misalnya: Salinator } \\
\text { fragilis, Brotia costula. }\end{array}$
\end{tabular}

\begin{tabular}{|c|c|c|c|c|}
\hline $\begin{array}{l}\mathrm{K} / \\
\mathrm{SK}\end{array}$ & $\begin{array}{l}\text { Materi Ajar Tuntutan } \\
\text { Kurikulum } 2013\end{array}$ & $\begin{array}{l}\mathrm{K} / \\
\mathrm{SK}\end{array}$ & $\begin{array}{l}\text { Materi Ajar Hasil Penelitian di } \\
\text { Sungai Gajah Wong }\end{array}$ & Keterangan \\
\hline K & $\begin{array}{l}\text { Mengelompokkan tumbuhan } \\
\& \text { hewan }\end{array}$ & K & $\begin{array}{l}\text { Mengelompokkan tumbuhan } \& \\
\text { hewan }\end{array}$ & \\
\hline SK-I & Kriteria klasifikasi tumbuhan & SK-I & & \\
\hline SK-2 & Kriteria klasifikasi hewan & SK-2 & Kriteria klasifikasi hewan & $\begin{array}{l}\text { Terpenuhi. Didasarkan pada ciri } \\
\text { morfologi invertebrata yang ditemukan. }\end{array}$ \\
\hline SK-3 & Kunci determinasi & SK-3 & & \\
\hline SK-4 & Kunci dikotomi & SK-4 & Kunci dikotomi & $\begin{array}{l}\text { Terpenuhi. Dibuat kunci dikotom } \\
\text { berdasarkan invertebrata yang ditemukan. }\end{array}$ \\
\hline
\end{tabular}




\begin{tabular}{|c|c|c|c|c|}
\hline $\begin{array}{l}\mathrm{K} / \\
\mathrm{SK}\end{array}$ & $\begin{array}{c}\text { Materi Ajar Tuntutan } \\
\text { Kurikulum } 2013\end{array}$ & $\begin{array}{l}\mathrm{K} / \\
\mathrm{SK}\end{array}$ & $\begin{array}{l}\text { Materi Ajar Hasil Penelitian di } \\
\text { Sungai Gajah Wong }\end{array}$ & Keterangan \\
\hline $\begin{array}{l}\mathrm{K} / \\
\mathrm{SK}\end{array}$ & $\begin{array}{c}\text { Materi Ajar Tuntutan } \\
\text { Kurikulum } 2013\end{array}$ & $\begin{array}{l}\mathrm{K} / \\
\mathrm{SK}\end{array}$ & $\begin{array}{l}\text { Materi Ajar Hasil Penelitian di } \\
\text { Sungai Gajah Wong }\end{array}$ & Keterangan \\
\hline K & $\begin{array}{l}\text { Klasifikasi mikroskopis } \\
\text { bakteri \& jamur }\end{array}$ & K & $\begin{array}{l}\text { Klasifikasi mikroskopis bakteri \& } \\
\text { jamur }\end{array}$ & \\
\hline SK-I & Ciri-ciri bakteri & SK-I & & \\
\hline$\overline{\text { SK-2 }}$ & Struktur tubuh bakteri & SK-2 & & \\
\hline SK-3 & Reproduksi bakteri & SK-3 & & \\
\hline SK-3 & Macam-macam bakteri & SK-3 & & \\
\hline SK-4 & $\begin{array}{l}\text { Peranan bakteri bagi } \\
\text { kehidupan }\end{array}$ & SK-4 & & \\
\hline SK-5 & Ganggang biru & SK-5 & & \\
\hline $\begin{array}{l}\mathrm{K} / \\
\mathrm{SK}\end{array}$ & $\begin{array}{c}\text { Materi Ajar Tuntutan } \\
\text { Kurikulum } 2013\end{array}$ & $\begin{array}{l}\mathrm{K} / \\
\mathrm{SK}\end{array}$ & $\begin{array}{l}\text { Materi Ajar Hasil Penelitian di } \\
\text { Sungai Gajah Wong }\end{array}$ & Keterangan \\
\hline $\mathrm{K}$ & Klasifikasi tumbuhan $\&$ hewan & $\mathrm{K}$ & Klasifikasi tumbuhan $\&$ hewan & \\
\hline SK-I & $\begin{array}{l}\text { Klasifikasi tumbuhan } \\
\text { (Bryophyta, Pteridophyta, } \\
\text { Spermatophyta) }\end{array}$ & SK-I & & \\
\hline SK-2 & $\begin{array}{l}\text { Klasifikasi hewan (Vertebrata } \\
\text { \& Invertebrata) }\end{array}$ & SK-2 & Klasifikasi ilmiah invertebrata & $\begin{array}{l}\text { Terpenuhi. Dilakukan menggunakan } \\
\text { sistem klasifikasi Linnaeus, sedangkan } \\
\text { klasifikasi ilmiah vertebrata tidak } \\
\text { dilakukan dalam riset. }\end{array}$ \\
\hline
\end{tabular}

2. Hasil analisis mendalam ketentuan materi ajar yang ditemukan

Tabel 2. Keterpenuhan Kriteria dan Prinsip Materi Ajar Klasifikasi Hewan Invertebrata di Area Sungai Gajah Wong Kabupaten Bantul

\begin{tabular}{|c|c|c|c|c|c|c|c|}
\hline \multirow{3}{*}{ HASIL } & \multicolumn{4}{|c|}{ KRITERIA MATERI AJAR } & \multicolumn{3}{|c|}{ PRINSIP MATERI AJAR } \\
\hline & \multicolumn{2}{|c|}{ PENGETAHUAN } & \multirow{2}{*}{ SIKAP } & \multirow{2}{*}{$\begin{array}{c}\text { KETRAMPILA } \\
\mathrm{N}\end{array}$} & \multirow{2}{*}{ Relevansi } & \multirow[b]{2}{*}{ Adequasi } & \multirow{2}{*}{ Konsistensi } \\
\hline & FAKTA & KONSEP & & & & & \\
\hline $\begin{array}{l}\text { Pengertian } \\
\text { klasifikasi } \\
\text { makhluk hidup } \\
\text { beserta hakekat } \\
\text { dan tujuan } \\
\text { pengelompokan. }\end{array}$ & $\begin{array}{l}\text { Klasifikasi makhluk } \\
\text { hidup adalah cara } \\
\text { memilah dan } \\
\text { mengelompokkan } \\
\text { makhluk hdup } \\
\text { menjadi unit-unit } \\
\text { tertentu. Tujuannya } \\
\text { untuk } \\
\text { menyederhanakan } \\
\text { obyek studi yang } \\
\text { beranekaragam, } \\
\text { sehingga } \\
\text { mempermudah } \\
\text { mengenalinya. }\end{array}$ & $\begin{array}{l}\text { Klasifikasi } \\
\text { makhluk hidup } \\
\text { (klasifikasi hewan) }\end{array}$ & $\begin{array}{l}\text { I.Siswa dapat } \\
\text { bekerja sama } \\
\text { dengan } \\
\text { anggota } \\
\text { kelompok } \\
\text { maupun } \\
\text { anggota yang } \\
\text { lain selama } \\
\text { kegiatan } \\
\text { pembelajaran. } \\
\text { 2.Siswa mampu } \\
\text { belajar } \\
\text { mandiri }\end{array}$ & & $\sqrt{ }$ & $\sqrt{ }$ & $\sqrt{ }$ \\
\hline $\begin{array}{l}\text { Prosedur } \\
\text { klasifikasi }\end{array}$ & $\begin{array}{l}\text { Prosedur } \\
\text { klasifikasi hewan } \\
\text { didasarkan pada } \\
\text { persamaan dan } \\
\text { perbedaan ciri-ciri } \\
\text { morfologi yang } \\
\text { dimiliki }\end{array}$ & $\begin{array}{l}\text { Prosedur } \\
\text { pengklasifikasian } \\
\text { makhluk hidup }\end{array}$ & $\begin{array}{l}\text { 3.Siswa mampu } \\
\text { menerima } \\
\text { pendapat } \\
\text { orang lain } \\
\text { dengan } \\
\text { kegiatan }\end{array}$ & $\begin{array}{l}\text { Siswa } \\
\text { trampil } \\
\text { mengklasifik } \\
\text { asikan jenis } \\
\text { hewan yang } \\
\text { ditemukan }\end{array}$ & $\sqrt{ }$ & $\sqrt{ }$ & $\sqrt{ }$ \\
\hline $\begin{array}{l}\text { Sistem tata nama } \\
\text { makhluk hidup }\end{array}$ & $\begin{array}{l}\text { Menggunakan } \\
\text { sistem tata nama } \\
\text { binomial } \\
\text { nomenclature, } \\
\text { misalnya: } \\
\text { Salinator fragilis, } \\
\text { Helictus sp. }\end{array}$ & $\begin{array}{l}\text { Sistem penamaan } \\
\text { ilmiah binomial } \\
\text { nomenclature }\end{array}$ & $\begin{array}{l}\text { diskusi } \\
\text { 4.Siswa mampu } \\
\text { melakukan } \\
\text { langkah- } \\
\text { langkah upaya } \\
\text { peduli }\end{array}$ & $\begin{array}{l}\text { Siswa } \\
\text { trampil } \\
\text { menuliskan } \\
\text { nama-nama } \\
\text { ilmiah } \\
\text { spesies yang } \\
\text { benar }\end{array}$ & $\sqrt{ }$ & $\sqrt{ }$ & $\sqrt{ }$ \\
\hline $\begin{array}{l}\text { Kriteria } \\
\text { klasifikasi } \\
\text { Hewan } \\
\text { Berdasarkan ciri }\end{array}$ & $\begin{array}{l}\text { Ciri yang } \\
\text { digunakan } \\
\text { meliputi ukuran } \\
\text { tubuh, jumlah }\end{array}$ & $\begin{array}{l}\text { Ciri-ciri morfologi } \\
\text { (kriteria klasifikasi } \\
\text { hewan) }\end{array}$ & $\begin{array}{l}\text { terhadap } \\
\text { kelestarian } \\
\text { hewan-hewan } \\
\text { di sungai. }\end{array}$ & $\begin{array}{l}\text { Siswa trampil } \\
\text { mengidentifik } \\
\text { asi hewan } \\
\text { berdasarkan }\end{array}$ & $\sqrt{ }$ & $\sqrt{ }$ & $\sqrt{ }$ \\
\hline
\end{tabular}




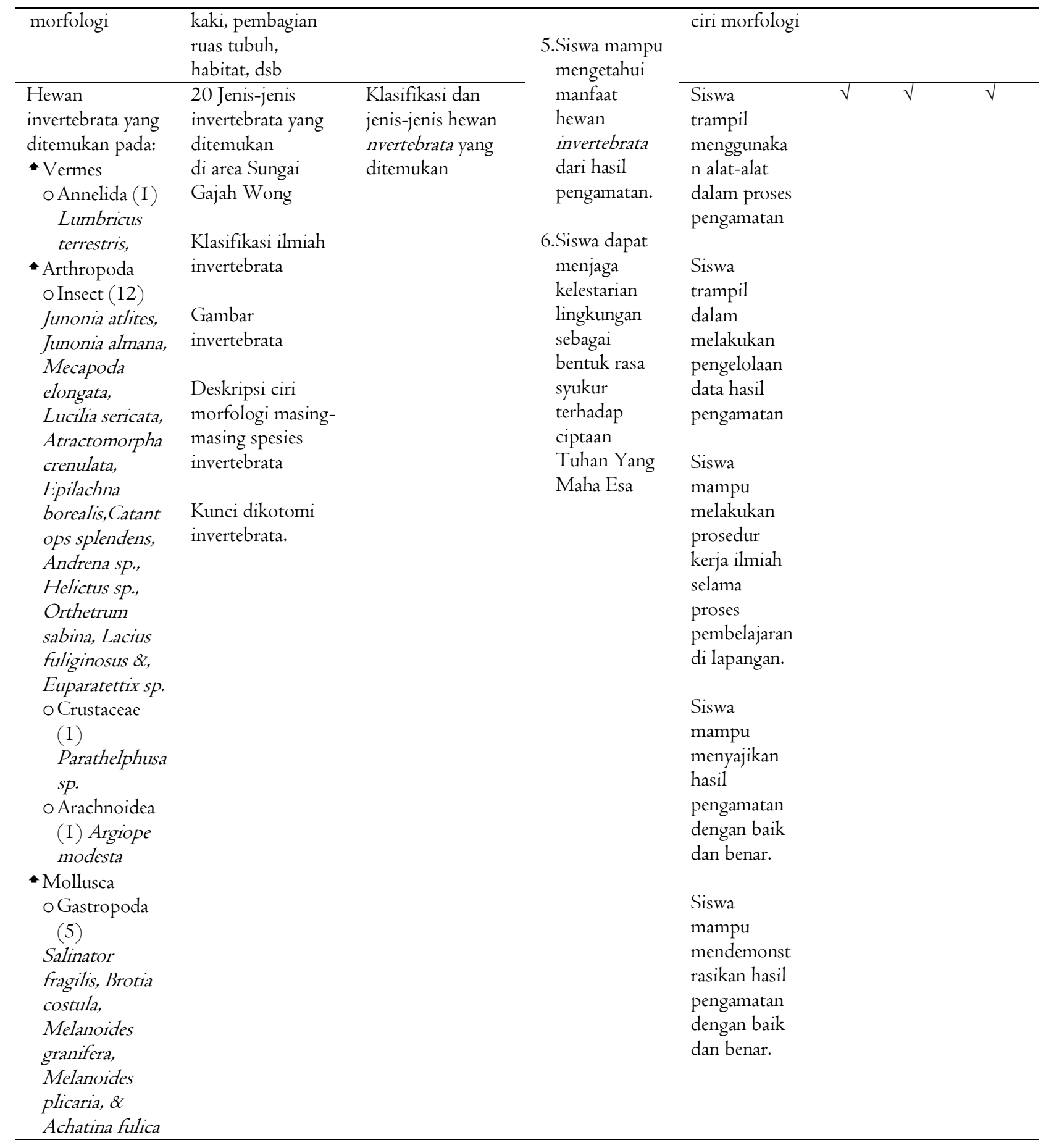

\section{Data Hasil Penilaian Produk}

Data hasil penilaian buku suplemen materi ajar oleh guru IPA (Biologi) SMP dapat disajikan pada Tabel 3 sebagai berikut.

Tabel 3. Kualitas Buku Suplemen Materi Ajar Klasifikasi Hewan Invertebrata Berdasarkan Penilaian Guru IPA (Biologi) SMP

\begin{tabular}{clcc}
\hline \multirow{2}{*}{ Aspek } & Komponen & $\begin{array}{c}\text { Persentase } \\
(\%)\end{array}$ & Kategori \\
\hline \multirow{3}{*}{ Materi } & Relevansi & I00 & Baik \\
\cline { 2 - 4 } & Konsistensi & 100 & Baik \\
\cline { 2 - 4 } & Adequacy & 94,6 & Baik \\
\hline
\end{tabular}

\begin{tabular}{clcc}
\hline Aspek & Komponen & $\begin{array}{c}\text { Persentase } \\
(\%)\end{array}$ & Kategori \\
\hline \multirow{2}{*}{ Penyajian } & Tampilan & I00 & Baik \\
\cline { 2 - 4 } & $\begin{array}{l}\text { Aturan } \\
\text { Penulisan }\end{array}$ & I00 & Baik \\
\hline Keterbacaan & Kebahasaan & 75 & Baik \\
\hline \multicolumn{2}{c}{ Keseluruhan } & 94,9 & Baik \\
\hline
\end{tabular}

Berdasarkan Tabel 3, penilaian kualitas buku suplemen materi ajar yang dinilai oleh guru IPA (Biologi) SMP dapat disajikan dalam Gambar 3. 


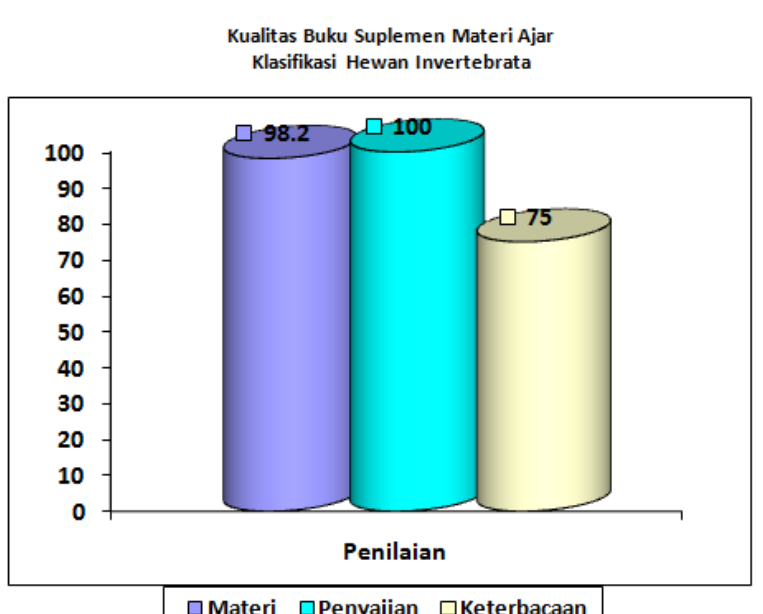

Gambar I. Diagram Penilaian Kualitas Buku Suplemen Materi Ajar Klasifikasi Hewan Invertebrata Berdasarkan Penilaian Guru IPA (Biologi) SMP

Berdasarkan uji penilaian oleh guru IPA (Biologi) SMP diperoleh hasil bahwa buku suplemen materi ajar Klasifikasi Hewan invertebratadalam kategori baik dengan presentase 94,9\%. Semua aspek yang rata-rata menunjukkan hasil jawaban "Ya". Hal tersebut menunjukkan bahwa buku suplemen materi ajar yang disusun memperoleh predikat layak digunakan untuk tambahan materi pembelajaran yang berbasis pada potensi lokal di wilayah Kabupaten Bantul dan tidak menutup kemungkinan bisa digunakan sebagai model bagi wilayah-wilayah lain pada materi ajar yang sejenis.

\section{Revisi Produk}

Revis produk dilakukan untuk menyempurnakan produk buku suplemen materi ajar yang telah dikembangkan. Revisi produk dilakukan setelah memperoleh penilaian dari uji ahli, yaitu guru IPA (Biologi) SMP. Berikut merupakan masukan dari catatan-catatan guru IPA (Biologi) SMP tentang suplemen materi ajar yang sudah disusun untuk direvisi disajikan dalam Tabel 4.

Tabel 4. Hasil Revisi Buku Suplemen Materi Ajar Klasifikasi Hewan Invertebrata Sebelum dan Sesudah Penilaian dari Guru IPA (Biologi SMP)

\begin{tabular}{|c|c|}
\hline Sebelum Revisi & Sesudah Revisi \\
\hline \multicolumn{2}{|c|}{$\begin{array}{l}\text { Ada beberapa istilah yang belum sesuai dengan karakteristik siswa } \\
\text { SMP: }\end{array}$} \\
\hline Hal $5=$ clitellum & $\begin{array}{l}\text { Hal } 5=\text { alat reproduksi pada } \\
\text { cacing }\end{array}$ \\
\hline Hal I8 = whorl & Hal I8 = cangkang \\
\hline \multicolumn{2}{|c|}{$\begin{array}{l}\text { Perlu penyempurnaan pada penulisan kata/kalimat yang sesuai } \\
\text { EYD: }\end{array}$} \\
\hline Hal.i = keanekragaman & Hal. i = keanekaragaman \\
\hline Hal I = makhluk ... & Hal I = makhluk hidup \\
\hline Hal 3 = Campell, dkk (2003) & Hal 3 = Campbell \\
\hline Hal 3 = linfkunganya & Hal 3 = lingkungannya \\
\hline $\begin{array}{l}\text { Hal } 3=(\text { Sumarwan, } \mathrm{dkk} \\
(2007: 8 \mathrm{I}))\end{array}$ & $\begin{array}{l}\text { Hal } 3=\text { (Sumarwan dkk, } \\
\text { 2007: 8I) }\end{array}$ \\
\hline Hal $4=$ konjugasai & Hal 4 = konjugasi \\
\hline Hal 4 = Colenterata & Hal $4=$ Coelenterata \\
\hline Hal $4=$ alatperaba & Hal $4=$ alat peraba \\
\hline
\end{tabular}

\begin{tabular}{|c|c|}
\hline Sebelum Revisi & Sesudah Revisi \\
\hline Hal $4=$ medua & Hal $4=$ medula \\
\hline Hal $4=$ Fascioloa hepatica & Hal $4=$ Fasciola hepatica \\
\hline Hal $4=$ sapai & Hal $4=$ sapi \\
\hline \multicolumn{2}{|c|}{$\begin{array}{l}\text { Peta konsep sebaiknya ditampilkan hubungan antarkonsep } \\
\text { menggunakan kalimat penghubung (konektor): }\end{array}$} \\
\hline $\begin{array}{l}\text { Hal I = peta konsep tanpa } \\
\text { konektor }\end{array}$ & $\begin{array}{l}\text { Hal I = peta konsep ada } \\
\text { konektor (pada, jenis, } \\
\text { menggunakan) }\end{array}$ \\
\hline \multicolumn{2}{|c|}{$\begin{array}{l}\text { Gambar sebaiknya dilengkapi sumber (baik dokumen pribadi } \\
\text { atau sumber lainnya, buku/internet): }\end{array}$} \\
\hline $\begin{array}{l}\text { Hal 5-I6 = tidak ada sumber } \\
\text { gambar }\end{array}$ & $\begin{array}{l}\text { Hal 5-I6 = ada sumber } \\
\text { gambar } \\
\text { (Prihartini, 20I4). }\end{array}$ \\
\hline \multicolumn{2}{|l|}{ Penyesuaian daftar isi: } \\
\hline $\begin{array}{l}\text { Hal ii }= \\
\text { Materi A. Pengertian .... } \\
\qquad \begin{array}{l}\text { B. Klasifikasi hewan } \\
\text { Kunci dikotomi }\end{array}\end{array}$ & $\begin{aligned} & \text { Hal ii }= \\
& \text { Materi A. Pengertian ... } \\
& \\
& \text { B. Klasifikasi } \\
& \text { hewan } \\
& \text { C. Kunci } \\
& \text { dikotomi }\end{aligned}$ \\
\hline \multicolumn{2}{|c|}{$\begin{array}{l}\text { Hal 2-3 = sebaiknya diberi pengantar/prolog agar lebih } \\
\text { komunikatif: }\end{array}$} \\
\hline Hal $3=$ tidak ada pengantar & $\begin{array}{l}\text { Hal } 2=\text { ada pengantar. } \\
\text { Baiklah, untuk lebih } \\
\text { memperdalam materi silakan } \\
\text { kalian simak penjelasan } \\
\text { berikut ini. }\end{array}$ \\
\hline \multicolumn{2}{|l|}{ Aturan penulisan: } \\
\hline Hal $4=$ A. klasifikasi Hewan & $\begin{array}{l}\text { Hal } 4=\text { B. Klasifikasi } \\
\text { Hewan }\end{array}$ \\
\hline $\begin{array}{l}\text { Hal I0 = Gambar I0 Halictus } \\
\text { sp. dinaikkan ke halaman } \\
\text { sebelumnya }\end{array}$ & $\begin{array}{l}\text { Hal } 9=\text { Gambar I0 Halictus } \\
\text { sp. dinaikkan ke halaman } 9\end{array}$ \\
\hline $\begin{array}{l}\text { Hal I I = deskripsi mengenai } \\
\text { semut hitam I paragrat terlalu } \\
\text { panjang }\end{array}$ & $\begin{array}{l}\text { Hal I I = deskripsi mengenai } \\
\text { semut hitam menjadi } 2 \\
\text { paragraf }\end{array}$ \\
\hline Hal I6 = kerngka & Hal I6 = kerangka \\
\hline Hal I8 = B. Kunci Dikotomi & $\begin{array}{l}\text { Hal I8 = C. Kunci } \\
\text { Dikotomi }\end{array}$ \\
\hline Hal I9 $=$ Melnoides plicaria & $\begin{array}{l}\text { Hal } 19=\text { Melanoides } \\
\text { plicaria }\end{array}$ \\
\hline Hal $7=$ Mecapoda elongata & $\begin{array}{l}\text { Hal } 7=\text { (Belalang daun) } \\
\text { Mecapoda elongata }\end{array}$ \\
\hline
\end{tabular}

Revisi buku suplemen materi ajar dilakukan setelah mendapat penilaian dari guru IPA (Biologi) SMP. Berdasarkan saran dan masukan dari penilai (guru), peneliti perlu melakukan revisi terhadap produk buku suplemen materi ajar. Saran yang diberikan mengenai penulisan istilah/kata yang belum sesuai dengan EYD, alur peta konsep dan sumber gambar.Sebagai tindak lanjut, maka sebagian besar saran yang diberikan diterima untuk perbaikan penyusunan buku suplemen materi ajar.

Penelitian pengembangan buku suplemen materi ajar biologi SMP berdasarkan hasil penelitian eksplorasi potensi lokal di Sungai Gajah Wong Kabupaten Bantul, yaitu mengidentifikasi potensi materi klasifikasi hewan invertebrata. Berdasarkan analisis data yang diperoleh melalui hasil penelitian eksplorasi tersebut maka dihasilkan produk berupa materi ajar yang dikemas dalam bentuk buku suplemen. Dinamakan buku suplemen materi ajar karena buku ini berisi materi yang ringkas, spesifik, hanya mencakup sebagian kecil sub materi dari sebuah kompetensi dasar. Buku ini sifatnya 
sebagai pendukung materi pokok, karena materi yang dikembangkan hanya spesifik pada sub pokok bahasan mata pelajaran biologi tertentu. Materi dari buku suplemen materi ajar disusun berdasarkan hasil penelitian eksplorasi yang dikemas sedemikian rupa sehingga cocok untuk mendukung materi pokok siswa SMP kelas VII dengan harapan karena materi yang diungkap berdasarkan potensi lokal, maka peserta didik sangat familiar dengan materi di dalam buku tersebut, sehingga hal ini menjadi aspek yang diunggulkan bagi buku suplemen materi ajar dalam hasil penelitian ini.

Buku suplemen materi ajar yang disusun dengan berjudul "Buku Suplemen Materi Ajar Klasifikasi Hewan Invertebrata”. Buku suplemen materi ajar tersebut dikembangkan untuk mendukung Kompetensi Inti 3 memahami pengetahuan (faktual, konseptual, dan prosedural) berdasarkan rasa ingin tahunya tentang ilmu pengetahuan, teknologi, seni, budaya terkait fenomena, dan kejadian tampak mata dan 4 mencoba, mengolah, dan menyaji dalam ranah konkret (menggunakan, mengurai, merangkai, memodifikasi, dan membuat) dan ranah abstrak (menulis, membaca, menghitung, menggambar, dan mengarang) sesuai dengan yang dipelajari di sekolah dan sumber lain yang sama dalam sudut pandang/teori serta Kompetensi Dasar 3.3 memahami prosedur pengklasifikasian makhluk hidup dan benda-benda tak-hidup sebagai bagian kerja ilmiah, serta mengklasifikasikan berbagai makhluk hidup dan benda-benda tak-hidup berdasarkan ciri yang diamati, 4.3 mengumpulkan data dan melakukan klasifikasi terhadap benda-benda, tumbuhan, dan hewan yang ada di lingkungan sekitar.

Langkah kerja dari pengembangan buku suplemen materi ajar ini adalah sebagai berikut.

I. Melakukan penelitian eksplorasi potensi alam yang ada di Area Sungai Gajah Wong Kabupaten Bantul.

Potensi alam yang diungkap melalui penelitian eksplorasi dari Sungai Gajah Wong yang menjadi obyek penelitian adalah aliran Sungai Gajah Wong yang melintasi Desa Wirokerten, Bantul. Di Sungai Gajah Wong, kaya akan Gastropoda. Sesuai hasil penelitian Handayani (Prihartini, 2014) menunjukan bahwa di Desa Worokerten ditemukan jenis Gastropoda terbanyak.Banyaknya Gastropoda yang ditemukan di area tersebut menunjukan bahwa pada area tersebut kondisi sungai masih belum tercemar. Hal ini karena Gastropoda merupakan kelompok hewan yang dapat dijadikan sebagai indikator pencemaran. Hewan yang banyak ditemukan di Sungai Gajah Wong termasuk jenis hewan invertebrata, seperti berbagai jenis crustacea, pisces, insecta, arthropoda, gastropoda, dan amfibia (Prihartini, 20I4). Dengan demikian, potensi alam di Sungai Gajah Wong tersebut mendukung untuk dikembangkannya buku suplemen materi ajar klasifikasi hewan invertebrata.
2. Melakukan penelahaan hasil kajian penelitian eksplorasi untuk diidentifikasi potensinya sebagai materi ajar biologi di jenjang SMP yang sesuai dengan Kurikulum ang berlaku.

\section{a. Analisis hasil temuan materi ajar biologi}

Hasil analisis kesesuaian temuan materi ajar biologi materi klasifikasi invertebrata berdasarkan hasil penelitian eksplorasi klasifikasi hewan invertebrata di area Sungai Gajah Wong disajikan pada Tabel I. Berdasarkan hasil tersebut ditemukan beberapa konsep materi yang berpotensi menjadi materi ajar biologi, yaitu: klasifikasihewan invertebrate, kriteria klasifikasi hewan invertebrata, dan kunci dikotomi. Akan tetapi tidak semua konsep materi terpenuhi dalam temuan materi ajar, misalnya konsep pengelompokan tumbuhan, kunci determinasi, klasifikasi mikroskopis bakteri dan jamur, dan klasifikasi tumbuhan. Hal ini karena penelitian fokus pada jenis-jenis invertebrata yang dijumpai di Sungai Gajah Wong, sehingga materi yang ditemukan hanya mendukung materi klasifikasi hewan invertebrata.

Meskipun demikian, tidak semua phylum pada invertebrata ditemukan dalam penelitian. Beberapa phylum ada yang tidak dikaji dalam penelitian misalnya pada phylum Vermes, kelas Platyhelminthes dan Nemathelminthes tidak ditemukan dalam riset, sedangkan pada kelas Annelida diperoleh hasil I spesies, yaitu Lumbricus terrestris. Pada phylum Arthropoda ditemukan sebanyak I2 spesies yang termasuk kelas Insecta, yaitu Junonia atlites, Junonia almana, Mecapoda elongata, Lucilia sericata, Atractomorpha crenulata, Epilachna borealis, Catantops splendens, Andrena sp., Helictus sp., Orthetrum Sabina, Lacius fuliginosus, dan Euparatettix sp., I spesies termasuk kelas Crustaceae, yaitu Parathelphusa sp., I spesies termasuk kelas Arachnoidea, yaitu Argiope modesta, dan pada kelas Myriapoda tidak temukan dalam penelitian.

Pada phylum Mollusca, kelas Poecypoda dan Cephalopoda tidak ditemukan dalam penelitian, sedangkan kelas Gastropoda ditemukan sebanyak 5 spesies, yaitu Salinator fragilis, Brotia costula, Melanoides granifera, Melanoides plicaria, dan Achatina fulica. Pada phylum Echinodermata tidak ditemukan dalam penelitian. Total spesies yang ditemukan di Sungai Gajah Wong yaitu 20 spesies invertebrata. Jenis invertebrata yang diperoleh disertai dengan nama ilmiah dan nama daerah, deskripsi ciri morfologi, klasifikasi ilmiah, kunci dikotomi, dan gambar masing-masing spesies.

Berdasarkan hasil analisis mengenai kesesuaian materi hasil temuan dengan materi tuntutan kurikulum, dapat diketahui bahwa beberapa materi tidak ditemukan dalam penelitian. Hal ini menjadi peluang untuk dilakukan penelitian lebih lanjut 
terhadap materi yang belum pernah dilakukan dalam riset. Harapannya semua materi akan terpenuhi dan sesuai dengan tuntutan kurikulum. Meskipun demikian, secara keseluruhan isi materi dapat dikatakan sudah cukup terpenuhi karena sifatnya yang spesifik pada sub pokok bahasan tertentu.

b. Analisis mendalam ketentuan materi ajar yang ditemukan

Berdasarkan temuan-temuan materi berbasis potensi lokal melalui hasil penelitian eksplorasi di Sungai Gajah Wong sesuai dengan kebutuhan materi ajar biologi SMP. Materi yang ditemukan memenuhi prinsip-prinsip relevansi, adequacy, dan konsistensi. Relevansi artinya materi yang ditemukan ada kesesuaian dengan kebutuhan siswa SMP kelas VII. Ada kesesuaian dengan pencapaian tujuan pembelajaran dan kurikulum ang berlaku. Adequacy artinya materi yang ditemukan cukup mampu menghantarkan pada ketercapaian tujuan pembelajaran dan dapat dijadikan sebagai pengetahuan siswa. Prinsip selanjutnya yaitu konsistensi, artinya bahwa materi yang diperoleh tersajikan secara sistematis dan sesuai dengan urutan materi pada jenjang SMP. Selain itu, sebagai hasil perolehan peserta didik antara lain berupa aspek kognitif (pengetahuan), termasuk diantaranya (fakta dan konsep), aspek afektif (sikap), dan psikomotorik (ketrampilan). Masing-masing konsep materi memiliki hasil perolehan seperti yang tersaji pada Tabel 2.

c. Mendesain prototipe buku suplemen materi ajar sebagai wadah dari materi yang ditemukan dari hasil penelitian eksplorasi tersebut.

Pada tahap ini peneliti merancang desain dan sistematika buku suplemen materi ajar, yang meliputi:

I) Judul buku

Judul buku yang dikembangkan sesuai potensi obyek yang diungkap masing-masing. Judul bukunya antara lain: "Buku Suplemen Materi Ajar Klasifikasi Hewan Invertebrata".

2) Kompetensi inti dan kompetensi dasar

Pada bagian ini berupa kompetensi inti dan kompetensi dasar yang harus dicapai peserta didik. Kompetensi inti yang harus dicapai oleh peserta didik adalah sebagai berikut.

a) Kompetensi Inti 3 memahami pengetahuan (faktual, konseptual, dan prosedural) berdasarkan rasa ingin tahunya tentang ilmu pengetahuan, teknologi, seni, budaya terkait fenomena, dan kejadian tampak mata.

b) Kompetensi Inti 4 mencoba, mengolah, dan menyaji dalam ranah konkret (menggunakan, mengurai, merangkai, memodifikasi, dan membuat) dan ranah abstrak (menulis, membaca, menghitung, menggambar, dan mengarang) sesuai dengan yang dipelajari di sekolah dan sumber lain yang sama dalam sudut pandang/teori.

c) Kompetensi Dasar 3.3 memahami prosedur pengklasifikasian makhluk hidup dan bendabenda tak hidup sebagai bagian kerja ilmiah, serta mengklasifikasikan berbagai makhluk hidup dan benda-benda tak-hidup berdasarkan ciri yang diamati.

d) Kompetensi Dasar 4.3 mengumpulkan data dan melakukan klasifikasi terhadap benda-benda, tumbuhan, dan hewan yang ada di lingkungan sekitar.

3) Peta konsep

Peta konsep merupakan gambaran alur materi yang ada di dalam suplemen materi ajar. Fungsinya untuk mempermudah peserta didik dalam memahami materi.

4) Studi kasus/peristiwa/gambaran umum kekayaan alam suatu obyek.

Fungsi komponen ini sebagai stimulus/gambaran awal yang mengantarkan jalan pikiran siswa menuju pokok pembahasan. Hal ini dapat berupa studi kasus/peristiwa/gambaran umum kekayaan alam suatu obyek. Misalnya pada buku klasifikasi hewan invertebrata disajikan gambaran umum Sungai Gajah Wong.

5) Daftar pustaka

Daftar pustaka berisi referensi yang digunakan dalam mengembangkan suplemen materi ajar, sehingga apabila peserta didik ingin mencari informasi lebih lanjut dapat menelusuri acuan yang digunakan dalam mengembangkan suplemen materi ajar tersebut.

d. Mengujikan prototipe buku suplemen materiajar untuk mendapatkan penilaian kualitas terkait dengan materi, penyajian, dan keterbacaan dari buku suplemen materi ajar yang disusun.

Tahapan ini merupakan tahap uji terbatas oleh guru IPA (Biologi) SMP terhadap produk buku suplemen materi ajar yang telah disusun. Uji terbatas dilakukan dengan menggunakan instrumen penelitian yang berupa angket.Kisi-kisi intrumen penilaian yang digunakan mencakup 3 aspek, yaitu:

a) Aspek materi, terdiri dari 3 komponen yaitu relevansi/ kesesuaian, konsistensi/ keajegan, dan adequacy/kecukupan. Secara garis besar aspek materi memuat pertanyaan berkait dengan kebutuhan materi ajar IPA (biologi) SMP yang diperlukan dan sesuai dengan tuntutan kurikulum.

b) Aspek penyajian, mencakup tampilan dan aturan penulisan. Aspek ini memuat pertanyaan yang berkait dengan penyajian buku suplemen materi ajar. 
c) Aspek keterbacaan, berisi pertanyaan mengenai kebahasaan yang digunakan dalam buku suplemen materi ajar.

e. Menganalisis hasil pengujian desain buku suplemen materi ajar.

Berdasarkan analisis data yang diperoleh, setelah buku suplemen materi ajar disusun dan mendapat penilaian dari guru IPA (Biologi), secara keseluruhan buku suplemen materi ajar mendapatkan kategori baik. Penilaian tersebut ditinjau dari berbagai aspek diantaranya adalah aspek materi, aspek penyajian, dan aspek keterbacaan. Artinya ketiga suplemen materi ajar yang dikembangkan tersebut layak untuk digunakan dalam pembelajaran, baik di kelas maupun pembelajaran lapangan. Sesuai pendapat Mulyasa (2009), bahwa materi ajar adalah segala bentuk bahan yang digunakan untuk membantu guru/instruktur dalam melaksanakan kegiatan belajar mengajar dikelas. Materi pembelajaran (Instructional materials) berupa pengetahuan, keterampilan, dan sikap yang harus dikuasai peserta didik dalam rangka memenuhi standar kompetensi yang ditetapkan. Materi pembelajaran menempati posisi yang sangat penting dari keseluruhan kurikulum, yang harus dipersiapkan agar pelaksanaan pembelajaran dapat mencapai sasaran. Materi pembelajaran dipilih seoptimal mungkin untuk membantu peserta didik dalam mencapai standar kompetensi dan kompetensi dasar (Depdiknas, 2006).

Berdasarkan hasil penilaian buku suplemen materi ajar Klasifikasi Hawan Invertebrata oleh guru IPA (Biologi) pada ketiga aspek, baik aspek materi, penyajian, maupun keterbacaan memperoleh kategori baik. Secara keseluruhan dengan persentase 94,6\%. Pada instrumen penilaian produk rata-rata mendapat nilai satu dengan jawaban "Ya", terdapat satu jawaban "Tidak" pada aspek materi, yaitu pada indikator isi materi memperhatikan ranah/domain pembelajaran yang mencakup ranah kognitif/pengetahuan, ranah afektif/sikap, dan ranah psikomotorik/keterampilan yang akan diperoleh setiap peserta didik. Selanjutnya, dua jawaban "Tidak” pada aspek keterbacaan, yaitu pada indikator bahasa sesuai dengan tingkat perkembangan siswa SMP dan bahasa komunikatif.

Berdasarkan saran yang diberikan oleh guru dalam uji terbatasagar ranah afektif dan psikomotorik terdeteksi dengan jelas, maka sebaiknya dilengkapi dengan kegiatan belajar siswa. Dalam hal ini produk yang dibuat merupakan buku suplemen materi ajar, bukan merupakan modul. Jadi, produk tidak disertai latihan kegiatan siswa maupun evaluasi. Selain itu, saran penilai (guru) yaitu untuk menggunakan bahasa yang moderat/lunak sesuai tingkat perkembangan siswa SMP (bahasa santai, ringan dan sederhana). Meskipun demikian dalam catatan angket buku suplemen materi ajar tidak dijelaskan bagian yang harus direvisi.
Secara keseluruhan buku suplemen materi ajar tersebut memperoleh nilai baik. Menurut Sugiyono (20I3: I37), tingkat penilaian $X \leq 50 \%$ termasuk kategori kurang / rendah, sedangkan tingkat penilaian $50 \%<\mathrm{X} \leq \mathrm{I00} \%$ termasuk kategori baik/tinggi. Oleh karena buku suplemen materi ajar berturut-turut dengan nilai $94,9 \%$ dengan memperoleh kategori baik/tinggi. Artinya, buku suplemen materi ajar yang dikembangkan layak untuk digunakan dalam proses pembelajaran.

Tujuan pembuatan buku suplemen materi ajar adalah untuk melengkapi materi ajar yang sudah ada pada buku-buku ajar biologi SMP, dengan kelebihan terletak pada potensi lokal (local wisdom) yang diangkat sesuai dengan karakteristik kedaerahan. Namun demikin, suplemen materi ajar tetap dikembangkan melalui prinsip-prinsip dasar keilmuan. Menurut Palah (20II), prinsip-prinsip yang dijadikan dasar dalam menentukan materi pelajaran adalah kesesuaian (relevansi), keajegan (konsistensi), dan kecukupan (adequacy).

I. Relevansi artinya kesesuaian. Materi pembelajaran hendaknya relevan dengan pencapaian standar kompetensi dan pencapaian kompetensi dasar. Jika kemampuan yang diharapkan dikuasai peserta didik berupa menghafal fakta, maka materi pembelajaran yang diajarkan harus berupa fakta, bukan konsep atau prinsip ataupun jenis materi yang lain.

2. Konsistensi artinya keajegan. Jika kompetensi dasar yang harus dikuasai peserta didik ada empat macam, maka materi yang harus diajarkan juga harus meliputi empat macam.

3. Adequacy artinya kecukupan. Materi yang diajarkan hendaknya cukup memadai dalam membantu peserta didik menguasai kompetensi dasar yang diajarkan. Materi tidak boleh terlalu sedikit, dan tidak boleh terlalu banyak. Jika terlalu sedikit maka kurang membantu tercapainya standar kompetensi dan kompetensi dasar. Sebaliknya, jika terlalu banyak maka akan mengakibatkan keterlambatan dalam pencapaian target kurikulum (pencapaian keseluruhan SK dan KD) (Depdiknas, 2008: 5).

\section{Simpulan}

Berdasarkan hasil penelitian pengembangan buku suplemen materi ajar biologi SMP melalui hasil penelitian eksplorasi potensi lokal di area Sungai Gajah Wong Kabupaten Bantul dapat dibuat kesimpulan sebagai berikut.

I.Potensi materi ajar biologi yang dapat ditemukan di area Sungai Gajah Wong Kabupaten Bantul tentang keanekaragaman hewan invertebrata, berupa konsep: klasifikasi hewan invertebrata, kriteria klasifikasi hewan invertebrata, dan kunci dikotomi.

2. Secara keseluruhan temuanmateri berbasis potensi lokal di wilayah Kabupaten Bantul sesuai dengan 
kebutuhan materi ajar biologi SMP serta memenuhi prinsip-prinsip relevansi, adequacy, dan konsistensi.

3. Kualitas prototipe buku suplemen materi ajar yang dikembangkan dengan isi materi ajar berbasis potensi lokal di jenjang SMP memperoleh kategori baik dan layak untuk dijadikan sebagai tambahan materi ajar yang berbasis pada potensi lokal di area Sungai Gajah Wong Kabupaten Bantul dan sesuai dengan kurikulum 2013 dengan skor 94,9\% pada Buku Suplemen Materi Ajar Klasifikasi Hawan Invertebrata.

\section{Daftar Pustaka}

Depdiknas. 2006. Panduan Pengembangan Materi pembelajaran. Jakarta: Departemen Pendidikan Nasional, Direktorat Jenderal Manajemen Pendidikan Dasar dan Menengah, Direktorat pembinaan Sekolah Menengah Atas.

2008. Panduan Pengembangan Materi

Pembelajaran. Jakarta: Direktorat Jendral Manajemen Pendidikan Dasar dan Menengah Direktorat Pembinaan Sekolah Menengah Atas.

Mulyasa. 2009. Kurikulum Tingkat Satuan Pendidikan. Bandung: Remaja Rosdakarya.

Palah, Darul. 20II. "Makalah Materi Pembelajaran”. http://darulpalah.blogspot. com/2012/II/makalahmateri-pembelajaran.html. Diakses 26 November 2014.

Prihartini, Aprilia E. 20I4. Analisis Potensi Sumber Belajar IPA (Biologi) SMP Di Area Sungai Gajah Wong yang Melintasi Kabupaten Bantul untuk Penerapan KD 3.3 dan 4.3 Pada Sub Materi Klasifikasi Hewan Invertebrata. Yogyakarta: UAD.

Suratsih. 2010. Laporan Penelitian Potensi Lokal. Yogyakarta: Jurusan Pendidikan Biologi, FMIPA UNY.

Susilo, M. Joko. 2009. Diktat Pengembangan Bahan Ajar dalam Pembelajaran. Yogyakarta: UAD. 